CYTA - Journal of Food

\title{
USE OF POTASSIUM PERMANGANATE IN THE SUGAR APPLE POST-HARVEST PRESERVATION USO DE PERMANGANATO DE POTASIO EN LA PRESERVACIÓN POST-COSECHA DE FRUTAS DE CHIRIMOYA
}

M. A. Chaves , R. C. F. Bonomo , A. A. L. Silva , L. S. Santos , B. M. A. Carvalho , T. S. Souza , G. M. S Gomes \& R. D. Soares

To cite this article: M. A. Chaves , R. C. F. Bonomo, A. A. L. Silva , L. S. Santos , B. M. A. Carvalho , T. S. Souza, G. M. S Gomes \& R. D. Soares (2007) USE OF POTASSIUM PERMANGANATE IN THE SUGAR APPLE POST-HARVEST PRESERVATION USO DE PERMANGANATO DE POTASIO EN LA PRESERVACIÓN POST-COSECHA DE FRUTAS DE CHIRIMOYA, CYTA - Journal of Food, 5:5, 346-351, DOI: 10.1080/11358120709487711

To link to this article: https://doi.org/10.1080/11358120709487711

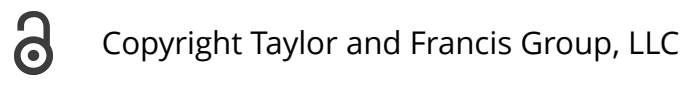

曲 Published online: 02 Oct 2009.

Submit your article to this journal $₫$

Џll Article views: 1041

Citing articles: 4 View citing articles $\square$ 


\title{
USE OF POTASSIUM PERMANGANATE IN THE SUGAR APPLE POST-HARVEST PRESERVATION
}

\section{USO DE PERMANGANATO DE POTASIO EN LA PRESERVACIÓN POST-COSECHADE FRUTAS DE CHIRIMOYA}

\author{
Chaves, M. A. ${ }^{1 *}$; Bonomo, R. C. F. ${ }^{1}$; Silva, A. A. L. ${ }^{1}$; Santos, L.S. ${ }^{2}$; Carvalho, B. M. A. ${ }^{2}$; \\ Souza, T. S. ${ }^{1}$; Gomes, G. M.S ${ }^{1}$; Soares, R. D. ${ }^{1}$
}

${ }^{1}$ Universidade Estadual do Sudoeste da Bahia - UESB, Campus Itapetinga. Praça Primavera, 40. Bairro Primavera Itapetinga, BA, Brazil, CEP 45700-000. ${ }^{2}$ Departamento de Tecnologia de Alimentos, Universidade Federal de Viçosa UFV. Av. P. H. Rolfs, s/n, Campus Universitário. Viçosa - MG, Brazil, CEP 36571-000.

Recibido/Received 20-04-2007; aceptado/accepted 05-06-2007

*Autor para la correspondencia/Corresponding author. E-mail: modesto@uesb.br

\begin{abstract}
The objective of this work was to evaluate the effect of the concentration of $\mathrm{KMnO}_{4}$ on post-harvest parameters of the sugar apple fruit (Annona squamosa, L.) packed in $0.1 \mathrm{~mm}$ thick PVC films. Groups of 4 fruits and a TNT bag with $\mathrm{KMnO}_{4}$, were wrapped in a PVC film and kept in a cold chamber at $16{ }^{\circ} \mathrm{C}$ with relative humidity between 90 and $100 \%$. A random experimental design was used in a $5 \times 4$ factorial scheme. The relationship of total soluble solids/titratable acidity presented different behavior comparing to the other variables, though it was possible to establish reasonable correlation taking the permanganate level and the storage time as independent variables and one of the following as a dependent variable: soluble solids level, $\mathrm{pH}$, titratable acidity and weight loss. It was concluded that $\mathrm{KMnO}_{4}$ delayed the maturity of the fruits, increased the period for fruits to hit maximum solid solutes content and increased the $\mathrm{pH}$ when it reached consumption period. It also decreased the titratable acidity.

\section{Resumen}

El objetivo de este trabajo, fue evaluar el efecto de la concentración de $\mathrm{KMnO}_{4}$ sobre algunos parámetros de poscosecha de la fruta de chirimoya (Annona squamosa, L.), empacadas con películas de PVC de 0,1mm de espesor. Grupos de 4 frutas y una bolsa de TNT con $\mathrm{KMnO}_{4}$, fueron envueltas en una película de PVC y colocados en una cámara a $16^{\circ} \mathrm{C}$ con humedad relativa entre 90 y $100 \%$. El diseño experimental fue totalmente al azar en un esquema factorial 5 x 4 . La relación sólidos solubles/acidez titulable presentó un comportamiento diferente a las otras variables pero fue posible establecer buenas correlaciones entre el nivel del permanganato o el tiempo de almacenamiento con cada una de las siguientes variables dependientes: contenido de sólidos solubles, $\mathrm{pH}$, acidez titulable y pérdida de peso. Se concluye que el efecto del $\mathrm{KMnO}_{4}$ fue retardar la maduración de las frutas aumentando el tiempo necesario para alcanzar el contenido máximo de sólidos solubles y el pH que tendrían al momento del consumo. El $\mathrm{KMnO}_{4}$ también diminuyó la acidez titulable.
\end{abstract}

Keywords: Sugar apple, potassium permanganate, titratable acidity Palabras clave: Chirimoya, permanganato de patasio, acidez tituable

\section{INTRODUCTION}

Despite being a highly appreciated fruit by consumers due to its excellent taste, sugar apple (Annona squamosa, L.) faces commercialization problems because of its perishableness. At room temperature, the postharvest shelf life of this fruit is only three to four days. For this reason it is only commercialized in the domestic market. Short shelf life, when associated with inadequate handling, results in production loss and hinders sugar apple commercialization. An immediate consequence is a raise of the product's price. Therefore, it is necessary to develop a technology which enables to extend the sugar apple post-harvest shelf life, reaching the consumer with its sensory qualities minimally altered and at compensatory prices.

Although official statistics are non-existent, the growing demand for annonaceae fruits is widely known, both in Brazilian domestic and in foreign markets. This is observed regarding the demand of publications about production, harvesting and post-harvesting of sugar apple and soursop (Mosca et. al., 2003).

There are two classes of fresh products in terms of ethylene production. There are climacteric products, mainly 
fruits that produce a burst of ethylene as ripen, as well an increase in respiration and there are the non-climacteric products that do not increase ethylene production when ripen. The more obvious way to establish in which class a product fits in is whether or not the product ripens after harvest. Products that ripen after harvest are classified as climacteric and they typically ripen by significantly softening, by changing color and by becoming sweeter (examples are bananas and nectarines). Non-climacteric fruits do not change significantly after harvest. They will soften a little, lose green color and develop rots as they become old but they do not improve their eating characteristics. Nonclimacteric crops include leafy vegetables, strawberries and grapes (Jobling, 2007).

Annonaceae fruits, such as the sugar apple, are climacteric as they increase respiratory activity and production of ethylene during ripening (Araujo et al., 1999). The increase of respiratory activity is accompanied by rapid modifications in its chemical composition, which alter the taste, aroma, firmness of the pulp and skin color. The development of suitable technology would enable the fruits quality conservation and would enable their shelf life prolongation (Kavati, 1997).

The use of PVC (polyvinyl chloride) film to create a modified atmosphere has shown satisfactory results for many fruits like guava and passion fruit, and has reduced loss of fresh weight (Lima and Durigan, 2000; Floriano et al., 2003). Santiago et al. (2003) noted a reduction in weight loss of fruits stored in PVC packing for sugar apples.

Among the large number of reagents and techniques that have been tested over the past years to remove ethylene from storage rooms whithout ventilation, potassium permanganate is the commercially used. A number of commercial potassium permanganate scrubbers are available in sachets, filters, blankets, and other specialized trapping devices (Sherman, 1985).

The inclusion of potassium permanganate, which is an ethylene absorbent, aims an extension of the storage period (Salunkhe and Desai, 1984).

When potassium permanganate in combination with polyethylene film is utilized, there is a longer fruit ripening delay (Chamara et al., 2000). Jiang et al. (1997) found that PVC packing ( $0.07 \mathrm{~mm}$ thickness) containing ethylene absorbers, $\mathrm{K}_{2} \mathrm{MnO}_{4}$-amargosite and $\mathrm{KMnO}_{4}$, respectively, was more efficient in prolonging conservation of post-harvest bananas, by offering a longer preclimacteric period. Strawberries, packed in PVC film containing ethylene absorbent $\left(\mathrm{KMnO}_{4}\right)$ stored at low temperatures, showed a decrease in respiratory rate and an increase in storage life from 20 to 30 days, maintaining the relationship sugars/acids acceptable for consumption (Hao and Hao, 1993). A higher value of total soluble solids/total titratable acidity (TSS/TTA) relationship indicates an agreeable taste due to the excellent combination of sugar and acid, while lower values correlate to acidity and bitter taste.
Experimental conditions utilized by various authors (Corrêa et al., 1995; Hong et al., 1996; Bhadra and Sen, 1997; Toivonen and Gorny, 1997; Yon et al., 1997; Kim and Wills, 1998) vary regarding polyethylene film thickness, with or without perforations, either using or not ethylene absorbers, or temperature, etc. Nevertheless, all of them concluded that polyethylene film packing, together with ethylene absorbers and low temperatures, led to a considerable increase in fruits shelf life, by increasing $\mathrm{CO}_{2}$ concentration, reducing water loss and respiration, inhibiting ethylene activity and consequently reducing the metabolism of the fruit.

The objective of this work was to evaluate the effect of the concentration of $\mathrm{KMnO}_{4}$ on post-harvest parameters of the sugar apple fruit (Annona squamosa, L.) packed in $0.1 \mathrm{~mm}$ thick PVC films.

\section{MATERIALAND METHODS}

Sugar apple fruit (Annona squamosa, L.) was picked up at its physiological ripeness stage, in the neighborhood of Rancho Alegre property (Latitude 14 ${ }^{\circ} 26^{\prime} 56^{\prime \prime} \mathrm{S}$, Longitude $41^{\circ} 04^{\prime} 41^{\prime \prime} \mathrm{W}$ and altitude $330 \mathrm{~m}$ ), in the city Anagé, Bahia, Brazil. The experimental period was from June to October 2003. The local climate can be classified, according to Koppen, as semi-arid and very hot, of the Bswh' type (Silva, 2004 ). The local soil is characterized as Tropic Eutrophic Haplic Cambisol Tb Class, which offers good drainage conditions (Silva, 2004 ).

According to Gaspar et al. (2000) the chemical and physical properties of sugar apple are affected by local factors such as soil and climate. This can also affect maturation period and the fruit's characteristics at consumption. The fruits from this property are being routinely accompanied by researchers from UESB. They have shown the following average characteristics of physiological ripeness: average weight of $350 \mathrm{~g}$; $\mathrm{pH}$ 5.65; total soluble solids (TSS) $21.5^{\circ}$ Brix and total titratable acidity (TTA) $0.40 \%$ of citric acid. When fully ripened: average weight of $392 \mathrm{~g}$; pH 5.3; total soluble solids (TSS) $25^{\circ}$ Brix and total titratable acidity (TTA) $0.39 \%$ of citric acid ( Ferrari et al., 1998; Gaspar et al. 2000; Silva et al., 2002; Dias et al., 2003). These characteristics were taken as reference in this work. The fruits were picked up and selected at the property and transported to the UESB Process Engineering Laboratory - Itapetinga Campus where they were treated and packed on the same day.

Groups of 4 fruits were randomly separated and weighed. Based on the weight of these fruits the $\mathrm{KMnO}_{4}$ weight was calculated to be packed together. The $\mathrm{KMnO}_{4}$ was put into a TNT (short for Tissue Not Tissue, which is a non specified synthetic polymer) bag and placed among the four fruits on an expanded polyestirene tray. The tray and fruits were wrapped in a PVC film and sealed in a manual sealer. 
After packing, the fruits were kept in a cold chamber at $16{ }^{\circ} \mathrm{C}$ and relative humidity between 90 and $100 \%$. pH (measured with a digital pH meter, QUMIS®), total soluble solids (measured with a portable ATAGO refractory meter), titratable acidity and weight loss (measured with an analytical GEAKA pair of scales) were analyzed according to the Adolfo Lutz Institute Rules (1995). A visual analysis of the inside and outside parts of the fruits was also performed. The experimental characterization used was entirely done in a $5 \times 4$ factorial scheme ( 5 levels of chemical factor: $\mathrm{KMnO}_{4}$ control at 3,6, 9, and $12 \%$, respectively and 4 levels of time factor: 2, 4, 7, and 12 days of storage), with 12 repetitions. The experimental unit was one tray with 4 fruits.

The results were analyzed by multiple regression analysis using the Sagata Regression Pro «statistical package». A quadratic model was utilized. The independent variables were the permanganate content and the number of post-harvest days. The dependent variables were individually: weight loss, total soluble solids content, $\mathrm{pH}$, titratable acidity and total soluble solids/titratable acidity relationship. Insignificant coefficients at $5 \%$ probability, from the Tukey test, were removed from the completed model. The deviations observed between and estimated values were also analyzed by residue graphs.

\section{RESULTSAND DISCUSSION}

The initial average values of fruit weight, $\mathrm{pH}$, total soluble solids (TSS), total titratable acidity (TTA) and TSS/ TTA relationship were: $0.408 \pm 0.2 \mathrm{~kg}, 5.61 \pm 0.01,21.4 \pm 0.1$ ${ }^{\circ}$ Brix, $0.348 \pm 0.005 \%$ of citric acid and $63.2 \pm 0.8^{\circ}$ Brix $/ \%$ citric acid, respectively. These values are very close to the historic average values from the property which were taken as reference.

Total soluble solids (TSS) content increased during storage period (Figure 1). The regression model found, Equation 1, takes into consideration only the linear effect of time period and the linear and quadratic effects of the permanganate content. As permanganate concentration gets higher, more time will take for soluble solids content to approximate the ripening level. Santiago et al. (2003) and Guimarães et al. (2003) observed the plastic packing effect on the delay in increasing soluble solids in sugar apple (Annona squamosa, L.). In this study, it was found that the increase in permanganate contributed to an increase of delay.

$$
\mathrm{TSS}=21.31+0.78 \mathrm{~T}-0.40 \mathrm{M}+0.02 \mathrm{M}^{2}
$$

Where: $\mathrm{T}$ is the time period in days and $\mathrm{M}$ is the permanganate level $(\% \mathrm{w} / \mathrm{w}) \cdot \mathrm{R}^{2}=0.970$.

The $\mathrm{pH}$ of the fruits showed a decrease during storage period (Figure 2). In this case, the regression model found (Equation 2) corresponds to the complete quadratric

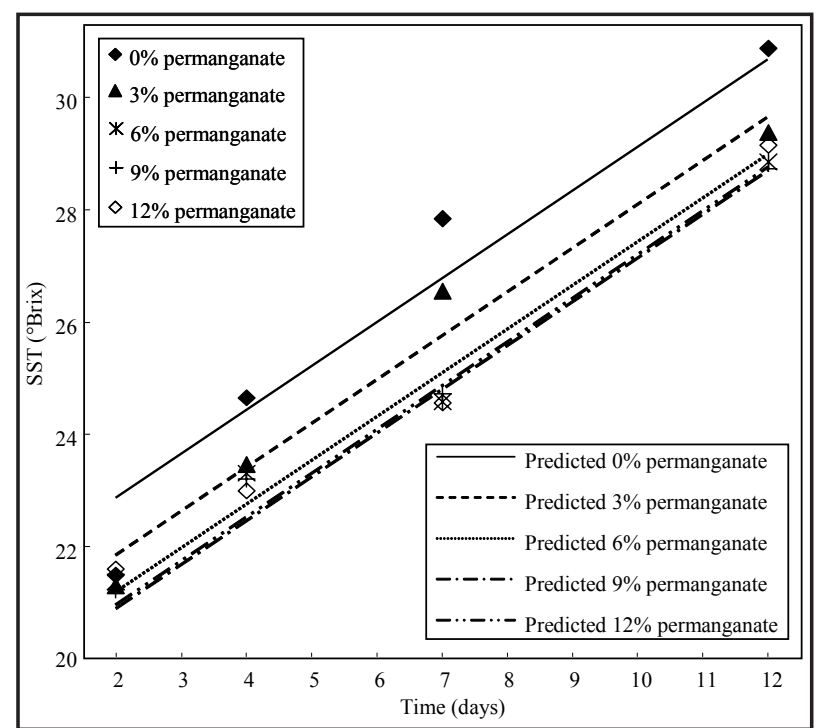

Figure 1. Soluble solids content as a function of storage time (at $16^{\circ} \mathrm{C}$ and relative humidity above $90 \%$ ) and permanganate level inside the PVC film packing, for sugar apple fruits (Annona squamosa, L.).

Figura 1. Volumen de sólidos solubles en función del tiempo del almacenamiento (a $16^{\circ} \mathrm{C}$ y humedad relativa $>90 \%$ ) y los niveles del permanganato dentro de la película de PVC, para chirimoya (Annona squamosa, L.).

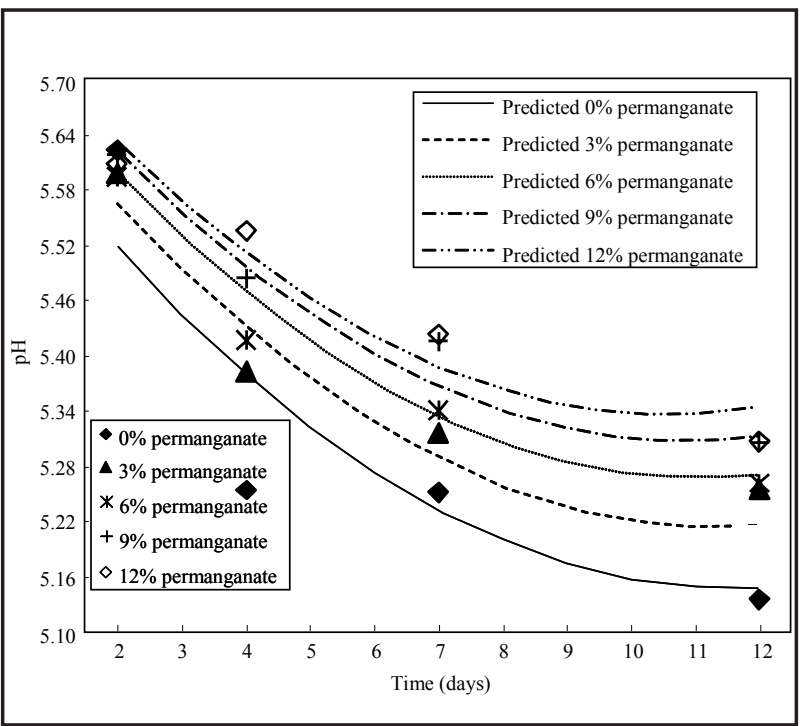

Figure 2. $\mathrm{pH}$ as a function of storage time period (at $16{ }^{\circ} \mathrm{C}$ and relative humidity above $90 \%$ ) and permanganate level inside the PVC film packing, for sugar apple fruits (Annona squamosa, L.).

Figura 2. $\mathrm{pH}$ en función del tiempo del almacenamiento (a 16 ${ }^{\circ} \mathrm{C}$ y humedad relativa $>90 \%$ ) y los niveles del permanganato dentro de la películas de PVC, para chirimoya (Annona squamosa, L.).

grade model. Santiago et al. (2003) did not observe the effect of plastic film packing on $\mathrm{pH}$ of sugar apple fruits, which indicates that the observed decrease here may be attributed to the permanganate. 


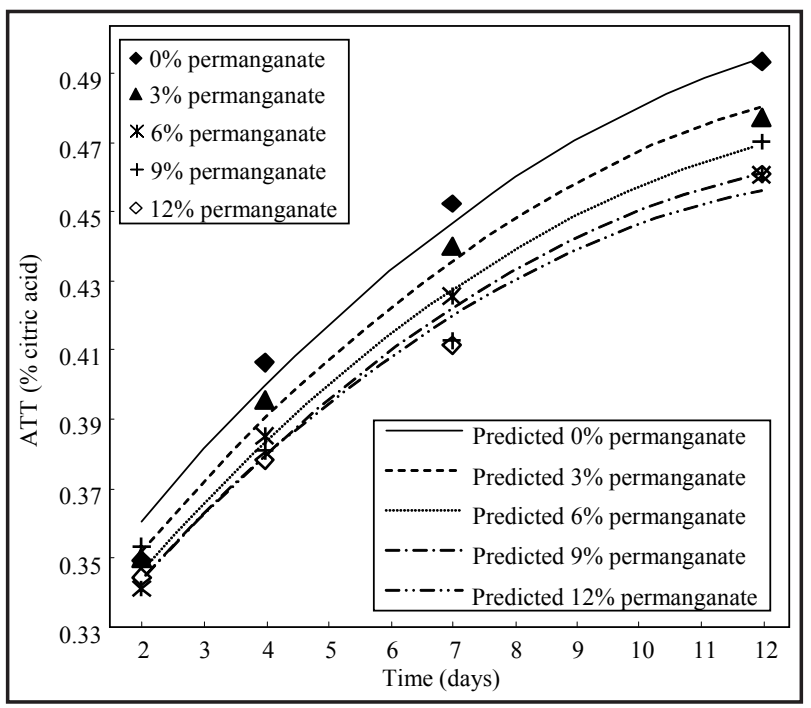

Figure 3. Titratable acidity as a function of storage time period (at $16{ }^{\circ} \mathrm{C}$ and relative humidity above $90 \%$ ) and permanganate level inside the PVC film packing, for sugar apple fruits (Annona squamosa, L.).

Figura 3. Acidez titulable en función del tiempo del almacenamiento (a $16^{\circ} \mathrm{C}$ y humedad relativa $>90 \%$ ) y los niveles del permanganato dentro de la película de PVC, para chirimoya (Annona squamosa, L.)

$$
\begin{aligned}
& \mathrm{pH}=5.6912-0.0938 \mathrm{~T}+0.0160 \mathrm{M}+0.0041 \mathrm{~T}^{2}- \\
& 0.0007 \mathrm{M}^{2}+0.0007 \mathrm{TM}
\end{aligned}
$$

Where: $\mathrm{T}$ is the time period in days and $\mathrm{M}$ is the permanganate level. $\mathrm{R}^{2}=0.901$.

Titratable acidity increased as stored (Figure 3 ). In this case, it was observed that an increase in the permanganate level inside the packing reduced the titratable acidity, consequently increasing the period for this variable to reach values equivalent to the property's historic values for ripe fruits. In this case the obtained regression model (Equation 3) was also the complete quadratic model, showing the linear and quadratic effects of time period and permanganate levels, as well as the importance of the variables interaction.

\section{$\mathrm{TTA}=0.3148+0.0245 \mathrm{~T}-0.0031 \mathrm{M}-0.0008 \mathrm{~T}^{2}+0.0002 \mathrm{M}^{2}-$ $0.002 \mathrm{TM}$

Where: $\mathrm{T}$ is the time period in days and $\mathrm{M}$ is the permanganate level $(\% \mathrm{w} / \mathrm{w}) \cdot \mathrm{R}^{2}=0.984$.

A weight loss increase was noted during storage period (Figure 4). The linear period effect of storage and the linear and quadratic effects of the permanganate level in the packing were observed for this variable. The effect of the product time period X permanganate levels was also observed. Equation 4 is the regression model obtained for this variable. Weight loss progressive increase was also observed by Guimarães at al. (2003) who studied the storage of sugar apple fruits in PVC packing, without the

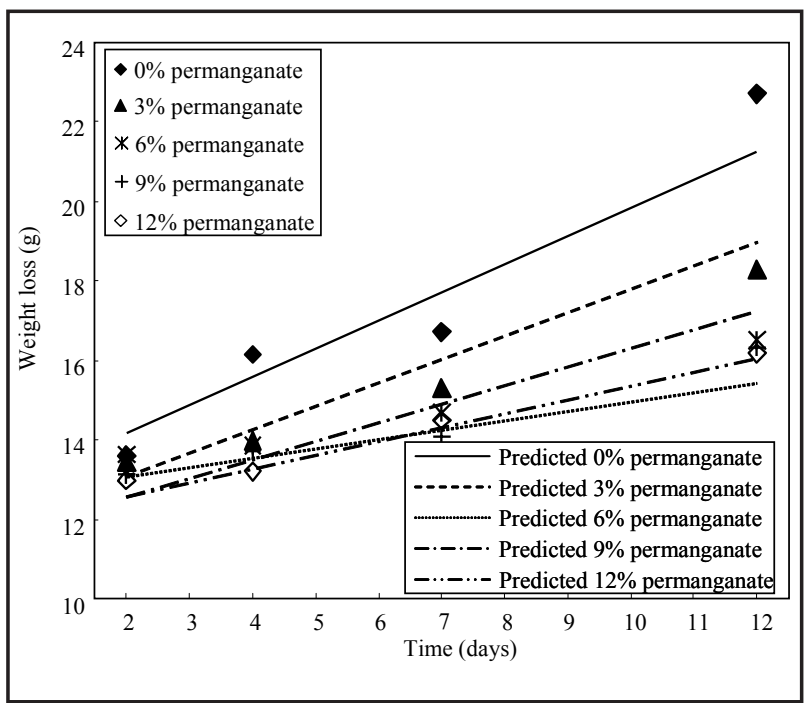

Figure 4. Weight loss as a function of storage time period (at $16{ }^{\circ} \mathrm{C}$ and relative humidity above $90 \%$ ) and permanganate level inside the PVC film packing, for sugar apple fruits (Annona squamosa, L.).

Figura 4. Pérdida de peso en función del tiempo del almacenamiento (a $16^{\circ} \mathrm{C}$ y humedad relativa $>90 \%$ ) y los niveles del permanganato dentro de la película de PVC, para chirimoya (Annona squamosa, L.).

addition of permanganate. It was observed from this work that the use of permanganate reduced weight loss intensity in relation to the control group which did not pass through treatment.

$$
\mathrm{WL}=12.75+0.71 \mathrm{~T}-0.37 \mathrm{M}+0.03 \mathrm{M}^{2}-4 \mathrm{TM} ; \mathrm{R}^{2}=0.921
$$

Where: WL is the weight loss, $\mathrm{T}$ is the time period in days and $\mathrm{M}$ is the permanganate level $(\% \mathrm{w} / \mathrm{w})$.

The results showed $\mathrm{KMnO}_{4}$ effect delayed fruits maturity, increased the period for fruits to reach maximum solid solutes content and increased $\mathrm{pH}$ of the fruit when it reaches consumption moment. It also decreased the titratable acidity. Contrary to other variables studied, the multiple regression quadratic model did not adjust to total soluble solids level and total titratable acidity (TSS/TTA) relationship. A simple linear regression equation for each level of permanganate was obtained for this variable (Figure 5 and Equations from 5 to 9).

$$
\begin{aligned}
& \text { TSS/TTA }=62.26+0.21 \mathrm{M}+0.02 \mathrm{M}^{2} ; \mathrm{R}^{2}=0.834 \\
& \text { TSS/TTA }=64.77+0.92 \mathrm{M}+0.07 \mathrm{M}^{2} ; \mathrm{R}^{2}=0.833 \\
& \text { TSS/TTA }=64.71+1.19 \mathrm{M}+0.10 \mathrm{M}^{2} ; \mathrm{R}^{2}=0.892 \\
& \text { TSS/TTA }=66.27+1.48 \mathrm{M}+0.10 \mathrm{M}^{2} ; \mathrm{R}^{2}=0.827 \\
& \text { TSS/TTA }
\end{aligned}
$$

A rapid reduction in TSS/TTA relationship levels was observed in all treatments from the second to fourth day of storage. From then all the values increased. This probably occurs because titratable acidity increased 


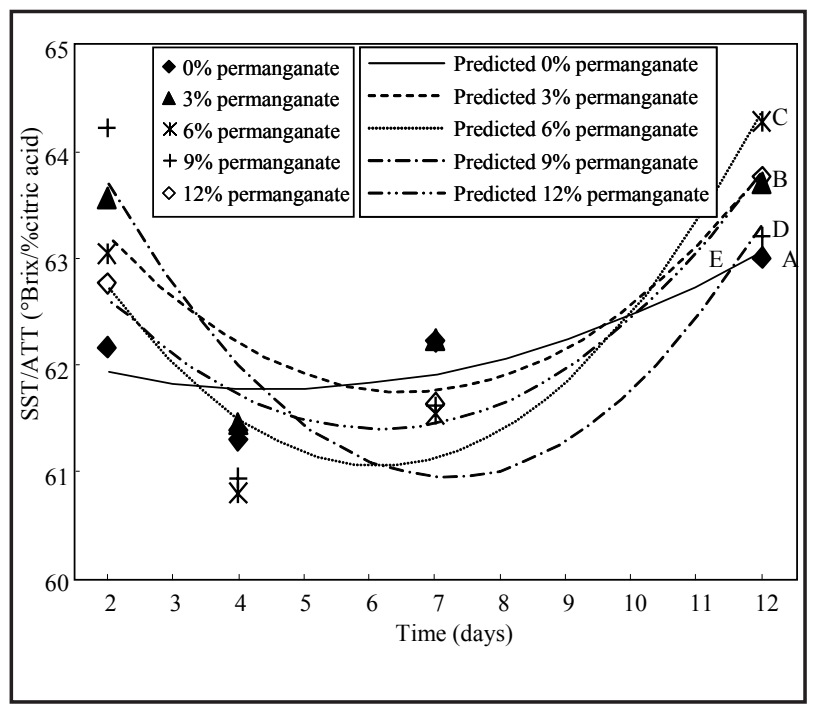

Figure 5. TSS/TTA as a function of storage time period (at $16{ }^{\circ} \mathrm{C}$ and relative humidity above $90 \%$ ) and permanganate level inside the PVC film packing, for sugar apple fruits (Annona squamosa, L.).

Figura 5. TSS/TTA en función del tiempo del almacenamiento (a $16{ }^{\circ} \mathrm{C}$ y humedad relativa sobre $90 \%$ ) y los niveles del permanganato dentro de la película de PVC, para chirimoya (Annona squamosa, L.).

rapidly during day zero to four and it is not accompanied by the level of soluble solids. Resende et al. (2001) utilizing benomyl and potassium permanganate in passion fruit reported a delay in (TSS/TTA) relationship and attributed the same to ethylene absorber, which role is to absorb and oxidize the ethylene liberated by the fruit itself during ripening. It is known that ethylene accelerates the ripening process, and its oxidation by ethylene absorber leads to a ripening delay. Nevertheless, we could observe in this work that this effect only took place in TSS/TTA relationship levels after the fourth day of storage.

Control group fruits were fully ripened on the fourth day. Their TSS/TTA and pH levels were equivalent to the properties' historic values.

For the treatment with $\mathrm{KMnO}_{4} 3$ and $6 \%$ the complete ripening occurred between the fourth and seventh day and consumption might be on the seventh day. On the twelfth storage day, some of the fruits had a pinkish color inside, which probably would lead to their disposement by the consumer. Various authors, among whom we quoted Mosca et al. (2003) and Guimarães et al. (2003), reported the skin darkening as an undesirable factor, though common in sugar apples. However, nothing was found in literature regarding the pinkish coloring.

For the treatment with $\mathrm{KMnO}_{4} 9 \%$ and $12 \%$ treatments, full ripening occurred between the seventh and twelfth day, and the fruits were in good condition to be consumed. Guimarães et al. (2003) also reported that on the $12^{\text {th }}$ day fruits that were packed in plastic film had a better internal appearance than the unpacked ones.

\section{CONCLUSION}

From the obtained results it can be concluded that it was possible to establish satisfactory correlations taking permanganate level and the storage time period as independent variables and as dependent variables, one of the following: soluble solids level, $\mathrm{pH}$, titratable acidity and weight loss. Although not all the models obtained were linear models.

The maturity of the fruits was delayed by the treatments with $\mathrm{KMnO}_{4}$, increasing the period for fruits to reach maximum solid solute content and increasing their $\mathrm{pH}$ when consumption moment is reached. It also decrease the titratable acidity.

\section{REFERENCES}

Araújo, J. F.; Araújo, J. F.; Alves, A. A. C. 1999. Instruções técnicas para o cultivo da pinha (Annona squamosa, L.). In EBDA Circular Técnica, EBDA, Salvador-Ba, Brazil, 34-37.

Badra, S.; Sen, S. K. 1997. Post-harvest storage of custard apple (Annona squamosa L.) fruit var. Local Green under various chemical and wrapping treatments. Journal of Inter academicia 1(4), 322-328.

Chamara, D., Illeperuma, K., Galappaatty, P. T. 2000. Effect of MA and ethylene absorbers on extension of storage life Kolikuttu banana at ambient temperature. Fruit 55, 361-388.

Correa, P. C.; Plaza Peraz, J. L. de la; Ruiz Altisent, M. 1995. No destructive tests to evaluate postharvest maturity in avocado. Agro Ciência 11(2), 197-200.

Dias, N. O.; Matsumoto, S. N.; Rebouças, T. N. R.; Viana, A. E. S.; São José, A. R.; Souza, I. V. B. 2003. Influência da poda de produção em ramos de diferentes diâmetros no desenvolvimento vegetativo e reprodutivo da pinheira. Revista Brasileira de Fruticultura 25(1), 100-103.

Ferrari, E. J.; Kavati, R.; Pelinson, G. J. B.; Nogueira, N. A. M. 1998. Influência de diferentes métodos de poda de verão para a produção tardia da fruta-do-conde. In: Congresso Brasileiro de Fruticultura, 15. Poços de Caldas, MG. Resumos. Lavras: UFLA, p.820 .

Floriano, C. M.; Santiago, A. S.; Rocha, M. C.; Coneglian, R. C. C.; Vasconcelos, M. A. S. 2003. Efeito do Cloreto de Cálcio, Permanganato de Potássio, e Embalagem de Polietileno na Conservação PósColheita do Maracujá Amarelo (Passiflora edulis F. Flavicarpa DEG) IN: Congresso Brasileiro de Fruticultura, anais, Sociedade Brasileira de Fruticultura, Fortaleza-CE.

Gaspar, J. W.; Sacramento, C. K. do; Cova, A. K. N.; Sanches, C. L. 2000. Mudanças físico-químicas durante o crescimento e desenvolvimento de frutos de pinha (Annona squamosa, L.). In: Congresso 
Brasileiro de Fruticultura, 16., 62, Fortaleza,CE. Resumos... Fortaleza: EMBRAPA agroindústria tropical / SBF, 2000. 1 CD-ROM.

Guimarães, A, A.; Praça, E. F.; Silva, P. S. L.; Medeiros, D. C.; Carneiro, C. L. 2003. Uso de Atmosfera Modificada e Refrigeração no Prolongamento da Vida Útil Pós-Colheita de Pinha (Annona squamosa, L.) IN: Congresso Brasileiro de Fruticultura, anais., Sociedade Brasileira de Fruticultura, Fortaleza-CE.

Hao, H. P.; Hao, L. 1993. Study on storing strawberry at a temperature near the freezing point of water. Journal of Fruit Science 10(1), 21-24.

Hong, Y. P.; Hong, S. S.; Kim, Y. B.; Kim, S. B. 1996. Effect ethylene absorbent (Frubel) on quality of «Hayward» kiwifruit during cold storage. RDA Journal of Agricultural Science, Far Management, Agricultural Engineering, Sericulture, and Farm Products Utilization 38(1), 922-926.

Jiang, Y. M.; Chen, F.; Liu, S. X.; Li, Y. Y. B. 1997. Effect of pre- and post-harvest treatments on the keeping quality of banana. Journal of Fruit Science 14(2), p.115-116.

Joblin, J. 2007. Postharvest Ethylene: A critical factor in quality management. Sydney Postharvest Laboratory Information Sheet.

Kavati, R. 1997. Embalagem e comercialização. In: São José, A.R. (ed.). Anonáceas: produção e mercado. Vitória da Conquista: UESB/DFZ, 257-262.

Kim, G. H.; Wills, R. B. H. 1998. Interaction of enhanced carbon dioxide and reduced ethylene on the storage life of strawberries. Journal of Horticultural Science and Biotechnology 73(2), 181-184.

Lima, M. A.; Durigan, J. F. 2000. Conservação de goiabas 'Pedro Sato', asssociando-se refrigeração com diferentes embalagens plásticas. Revista Brasileira de Fruticultura 22, 232-236.

Mosca, J. E.; Silva, E. O.; Mendonça, P. S.; Almeida, A. S.; Alves, R. E.; Miranda, M. R. A. 2003. Desenvolvimento de Tecnologia para Conservação Pós-colheita de Ata (Annona squamosa, L.). Proc. Interamer. Soc. Trop. Hort. 47, 114-118.
Resende, J. M.;Vilas Boas, E. V. B; Chitarra, M. S. F. 2001. Uso de atmosfera modificada na conservação póscolheita do maracujá amarelo. Ciência e Agrotecnologia 25, 159-168.

Salunkhe, D. K.; Desai, B. B. 1984. Postharvest Biotechnology of Fruits. 1. 43-57. Boca Raton: CRC Press.

Santiago, A. S.; Coneglian, R. C. C.; Busquet, R. N. B.; Vital, H. 2003. Avaliação Pós-Colheita de Frutos de Pinha (Annona squamosa L.) Submetidos a Diferentes Tratamentos Pós-Colheita IN: Congresso Brasileiro de Fruticultura, anais., Sociedade Brasileira de Fruticultura, Fortaleza-CE.

Sherman, M. 1985. Control of ethylene in the postharvest environment. HortScience 20, 57-60.

Silva, J. C. G. da. 2004. Monitoramento de variáveis ambientais do solo com diferentes tipos de cobertura morta na produção de pinha (Annona squamosa L.). Vitória da Conquista - BA: UESB, 79p. (Dissertação - Mestrado em Agronomia, Área de Concentração em Fitotecnia).

Silva, J. da.; Silva, E. S. da.; Silva, P. S. L. E. 2002. Determinação da qualidade e teor de sólidos solúveis nas diferentes partes do fruto de pinheira (Annona squamosa L.) Revista Brasileira de Fruticultura 24(2), 565-567.

Toivonen, P. M. A.; Gorny, J. R. 1997. Quality changes in packaged, diced onions (Allium cepa L.) containing two different absorbent materials. In: International Controlled Atmosphere Research Conference: Fruits other than apples and pears, Davis, CA. Proceedings. Davis, CA: University of California. Departament of Pomology, 1997. 3, 1-7. (Postharvest-Horticulture Series, 19).

Yon, R. M.; Rahman, A. S. A; Kader, A. A. M. 1997. A shipment of papaya cv. Eksotika. In: International Controlled Atmosphere Research Conference: Frech cut fruits and vegetables and MAP, Davis, CA. Proceedings. Davis, CA: University of California. Departament of Pomology, 5, 198-204. (Postharvest-Horticulture Series, 19). 